\title{
Mercury and Organic Carbon Distribution in Six Lakes from the North of Rio de Janeiro State
}

\author{
Wanderson Primo de Sousa ${ }^{*}$, Carlos Eduardo Veiga de Carvalho, Claudia Calasans Veiga \\ de Carvalho and Marina Satika Suzuki \\ Universidade Estadual do Norte Fluminense, Centro de Biociências e Biotecnologia, Laboratório de Ciências \\ Ambientais, Av. Alberto Lamego, 2000; carvalho@uenf.br; Parque Califórnia; 28013-602; Campos dos Goytacazes \\ - RJ, Brazil
}

\begin{abstract}
The objectives of the study was to evaluate the mercury contamination in sediments of six lagoons located in the north region of Rio de Janeiro State, trying to relate the Hg concentrations with factors that could influence it's mobility, such as organic carbon. The highest values observed in the superficial sediments in lakes like Campelo

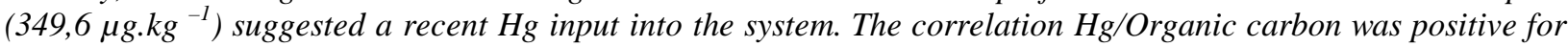
most areas, indicating that the organic carbon was a significant parameter for $\mathrm{Hg}$ retention in this region. The obtained results suggested that the mercury used as fungicide in agriculture lands and in gold mining areas in the past were probably responsible for the contamination of this environment.
\end{abstract}

Keywords: Mercury, organic carbon, sediment, lakes

\section{INTRODUCTION}

Mercury contamination has been considered one of the most hazards among anthropogenic impact upon the global environment. This element is one of the few metal pollutants that caused human death due to the ingestion of contaminated food (Lacerda and Solomons, 1991). According to Kudo et al., (1977), around $98 \%$ of $\mathrm{Hg}$ contamination in lake system is stored in the bottom sediment. By studying the metal distribution along sediments profiles it is possible to determine the contamination history for a region, and also retrieve important information about the background level of a given element (Solomons and Forstner, 1984). Several studies have strengthened the role of organic mater in regulating metallic pollutant behavior. Lodenius et al. (1984) showed that low organic mater concentrations was sufficient to retain a significant amount of $\mathrm{Hg}$ in sediments. Therefore, the organic mater determination seems to be an important tool in understanding and explaining the natural/anthropogenic $\mathrm{Hg}$ variation and distribution in sediments.

The past massive use of mercury fungicides in sugar cane plantations are the most important source of $\mathrm{Hg}$ contamination in the north of Rio de Janeiro State. This fungicide was used until 1980 when was prohibited by the State Government (Câmara 1990). Although not as significant as the use of $\mathrm{Hg}$ fungicides, the use of $\mathrm{Hg}$ in gold mining activities in Rio Paraiba do Sul river basin between 1986-1987 has probably caused a significant impact in raising $\mathrm{Hg}$ background levels in sediments and biota (Lima, 1990; Câmara, 1990; Lacerda et al., 1993; Souza, 1994; Primo, 2000).

*Author for correspondence 


\section{MATERIAL AND METHODS}

Surface sediments $(10 \mathrm{~cm}$ depth) were sampled with the help of a plastic spade in lower depths and with a box grab at higher depths $(>80 \mathrm{~cm})$ at four to six stations along each ecosystem. At least one sediment profile was sampled in the middle of the lake using acrylic tubes of $100 \mathrm{~cm}$ long with $7.0 \mathrm{~cm}$ of diameter. In the laboratory, the profiles were sliced with a stainless steal spatula at two centimeters interval until the first ten centimeters, and at five centimeters intervals along the rest of the sediment profile. After collecting, the samples were placed in plastic bags and kept in ice during the transport for the laboratory. In the laboratory the samples were dried $\left(40^{\circ} \mathrm{C}\right)$, homogenized and sieved $(<1 \mathrm{~mm})$. The samples were than kept in polyethylene flasks until assayed.
Total mercury was determined using the methodology described by Bastos et al. (1998), where $1.0 \mathrm{~g}$ of sediment was heated at $60^{\circ} \mathrm{C}$ on a hot plate for 5 minutes with $2 \mathrm{~mL}$ of water and 5 $\mathrm{mL}$ of ( $\left.3 \mathrm{HCl}: 1 \mathrm{HNO}_{3}\right)$. After cooling, $5 \mathrm{~mL}$ of water and $10 \mathrm{~mL}$ of $\mathrm{KMnO}_{4}(5 \%)$ were added and heated again for 15 minutes at $60{ }^{\circ} \mathrm{C}$. Drops of $\mathrm{NH}_{2} \mathrm{OH}$.HCL (12\%) were added after cooling; filtered and gauged to $25 \mathrm{~mL}$ with water. $\mathrm{Hg}$ was measured by atomic emission spectrophotometry with induced coupled plasma (ICP/AES Varian model Liberty II) with vapor generating accessory (VGA 77). The organic carbon determination was performed in a CHNS/O analyzer (Perkin Elmer, model 2400 Series II) (Calasans, 1998).

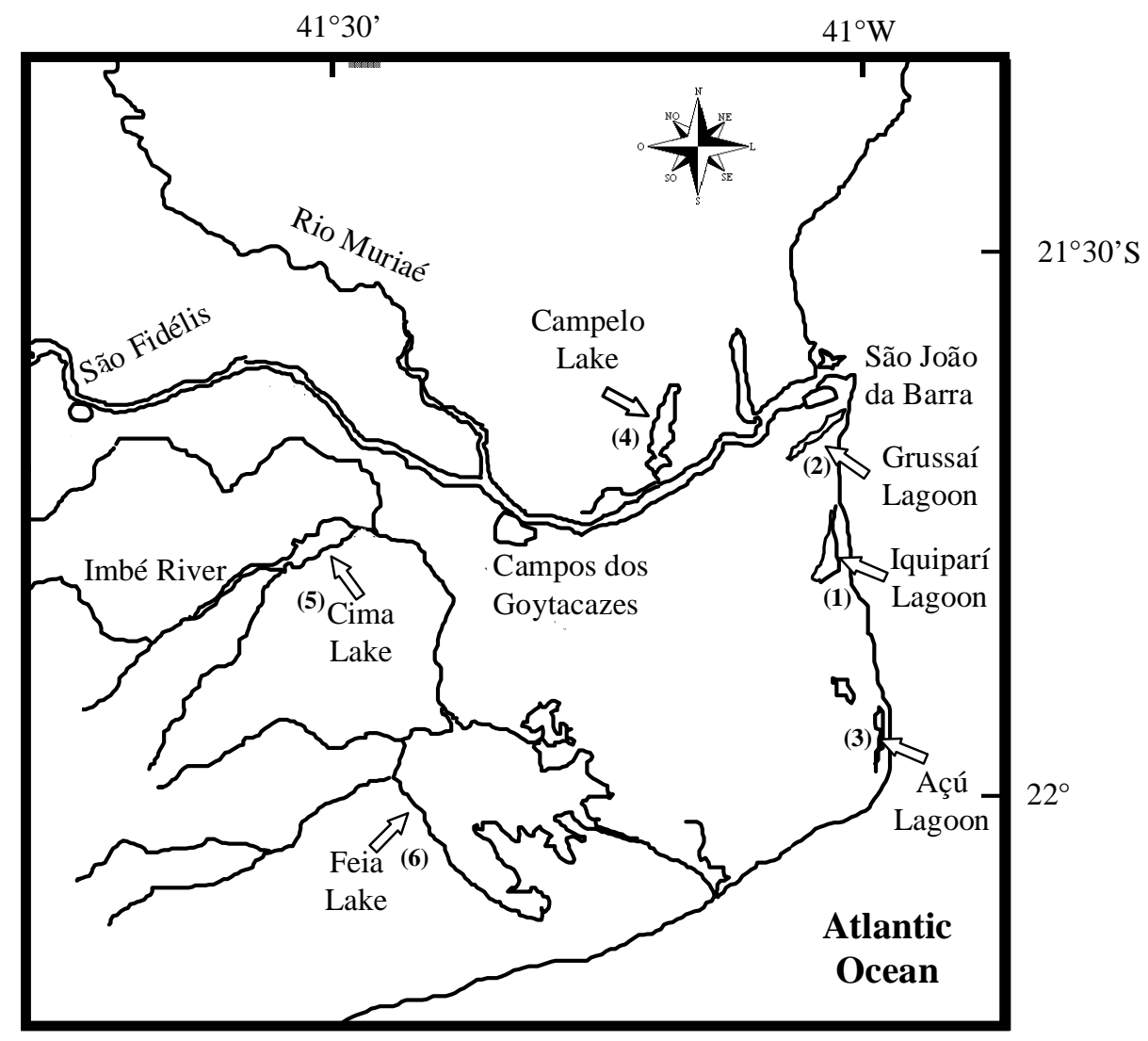

Figure 1 - Sampling site locations. 


\section{STUDY AREA}

The north of Rio de Janeiro State (Fig. 1), has its economy based mainly on sugar cane monoculture agriculture and cattle farming. In the last ten years the sugar cane culture declined and large areas have been occupied by other activities such as cattle farming, clay and sand extraction and horticulture.

Due to the importance of the lakes on the north of Rio de Janeiro State economy, mainly for fishing and tourist activities, these areas were chosen for the study.

Lagoons were chosen:

1) Iquipari lagoon located at the coast of São João da Barra municipality is a well-preserved lagoon, without any direct heavy metal contamination sources. It is surrounded by well-preserved Restinga vegetation.

2) Grussai lagoon located at the coast of São João da Barra, this lagoon is very impacted by urban occupation, mainly untreated domestic sewage discharge.

3) Açu lagoon located at the coastal region between Campos dos Goytacazes and São João da Barra. This lake is characterized as a preserved area.

4) Campelo lake located in Campos dos Goytacazes district near the metropolitan area. Pasture and sugar cane plantations surround the lake. This lake is an important fish producer to the municipal market of Campos dos Goytacazes.

5) Cima lake located $40 \mathrm{~km}$ from the coast of Campos dos Goytacazes. Cima Lake is an important tourist spot with large fish production. This lake receives the drainage of a well-preserved Atlantic Rain Forest.

6) Feia lake located between two cities (Campos and Quissamã), this lake is the biggest freshwater lake of Brazil. Fish production is the main economical activity.

\section{RESULTS}

The highest average $\mathrm{Hg}$ concentration in surface sediments samples were observed at the Campelo lake $\left(213 \pm 136.2 \mu \mathrm{g} \cdot \mathrm{kg}^{-1}\right)$, located near the Campos city, and surrounded by sugar cane plantations and pasture. The concentrations ranged from $71.3 \mu \mathrm{g} \cdot \mathrm{kg}^{-1}$ to $358 \mu \mathrm{g} \cdot \mathrm{kg}^{-1}$ in central region of the lake. The Iquipari lagoon, situated in coastal region of São João da Barra, presented the lowest mercury average concentrations among all the studied lagoons $\left(16.4 \pm 7.7 \mu \mathrm{g} \cdot \mathrm{kg}^{-1}\right)$, with values ranging from $0.5 \mu \mathrm{g} \cdot \mathrm{g}^{-1}$ to $33.3 \mu \mathrm{g} \cdot \mathrm{g}^{-1}$ in the middle of the lake (Table 1).

Table 1 - Average mercury and organic carbon concentrations (coefficient of variation in percentage) in surface sediments from all the studied lakes.

\begin{tabular}{lc|c}
\hline \multicolumn{1}{c}{ Sampling sites } & $\mathbf{H g}\left(\boldsymbol{\mu g} \cdot \mathbf{k g}^{-\mathbf{1}}\right)$ & $\mathbf{C \%}$ \\
\hline Iquipari $(\mathrm{n}=4)$ & $16(47)$ & $2,9(12)$ \\
Grussai $(\mathrm{n}=4)$ & $45(53)$ & $8,9(48)$ \\
Campelo $(\mathrm{n}=4)$ & $213(64)$ & $2,8(17)$ \\
Cima $(\mathrm{n}=5)$ & $158(22)$ & $3,3(63)$ \\
Açú $(\mathrm{n}=4)$ & $47(16)$ & $3,3(13)$ \\
Feia $(\mathrm{n}=6)$ & $92(31)$ & $3,1(46)$ \\
\hline
\end{tabular}

Organic carbon presented its highest values in Grussai Lagoon $(8.9 \pm 4.2 \%)$, and the others lakes presented values around 3\%. The Campelo Lake despite presenting the highest mercury averages, showed the lowest organic carbon average among the studied lagoons (2.8\%, Table 1).

Mercury and organic carbon distribution in sediment profiles showed, in most cases, an increase of the concentrations towards the surface (Fig.2), with a positive correlation with the concentrations of carbon $(\mathrm{p}<0,05)$.

The Iquipari and Açu lagoons presented a more homogeneous $\mathrm{Hg}$ profile when compared with the other studied lagoons. The observed values were near the concentration suggested by Souza (1994) as the background for the region $\left(40 \mu \mathrm{g} . \mathrm{kg}^{-1}\right)$. In Iquipari lagoon, $\mathrm{Hg}$ values range from $48 \mu \mathrm{g} \cdot \mathrm{kg}^{-1}$ in the upper layers (4 to $6 \mathrm{~cm}$ ) to $20.7 \mu \mathrm{g} \cdot \mathrm{kg}^{-1}$ in the bottom of the profile $(25$ to $33 \mathrm{~cm})$. In the Açú lagoon the concentrations ranged form $50.7 \mu \mathrm{g} \cdot \mathrm{kg}^{-1}$ in the upper layers $(0$ to $5 \mathrm{~cm})$ to $40.3 \mu \mathrm{g} \cdot \mathrm{kg}^{-1}$ in bottom layers $(15$ and $20 \mathrm{~cm})$. The organic carbon values followed the same trend in almost all depths, with value ranging between $15 \%$ and $2.1 \%$ in Iquipari and $4.6 \%$ and $2 \%$ in Açu lagoon. On the other hand Campelo Lake (Fig. 2), presented a higher variation in $\mathrm{Hg}$ concentrations along the studied profile. In the surface $(0-2 \mathrm{~cm})$ $\mathrm{Hg}$ value reached a maximum of $349 \mu \mathrm{g} . \mathrm{kg}^{-1}$, three times higher than the values (118.8 $\left.\mu \mathrm{g} \cdot \mathrm{kg}^{-1}\right)$ observed in middle deep $(2-5 \mathrm{~cm})$. 


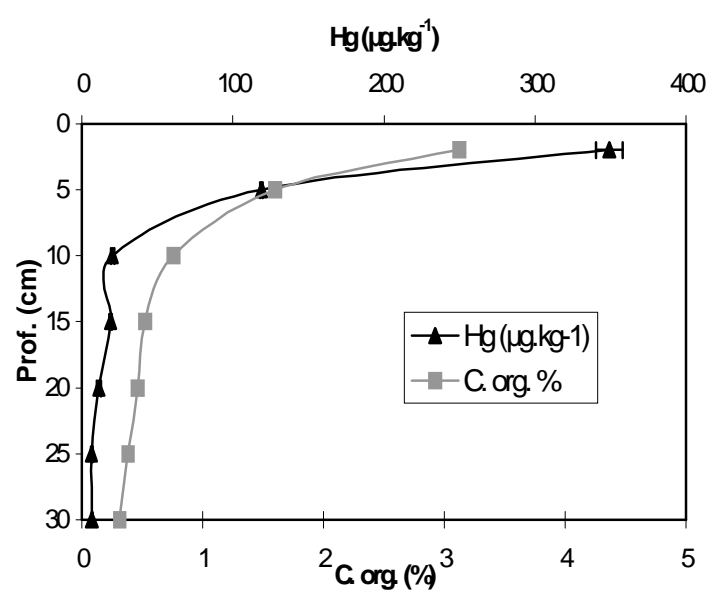

Figure 2 - Mercury and organic carbon distribution in a sediment profile from Campelo Lake.

The smaller values were observed between 25 and $30 \mathrm{~cm}$ deep $\left(6.52 \mu \mathrm{g} \cdot \mathrm{kg}^{-1}\right)$.

In both profiles from Feia Lake, $\mathrm{Hg}$ and organic carbon concentrations presented the same trend observed for the other studied lakes, with increasing concentrations at the top layers decreasing with depth. Small differences in the concentrations of the two profiles were observed. In the first profile, $\mathrm{Hg}$ and organic carbon values in the top layers were $101 \mu \mathrm{g} \cdot \mathrm{kg}^{-1}$ and $3.4 \%$, respectively, and in the second profile the surface values were $87.4 \mu \mathrm{g} \cdot \mathrm{kg}^{-1}$ and $4.1 \%$ respectively. Although both profiles presented similar distribution along the depths, the first profile didn't show a strong correlation between $\mathrm{Hg}$ and organic carbon ( $p>0.05$ ), the second profile presented a high correlation $(\mathrm{p}=0.00008)$.

The Cima Lake sediment profile showed its higher $\mathrm{Hg}$ value at $8-10 \mathrm{~cm}$ depth, (206.4 $\left.\mu \mathrm{g} \cdot \mathrm{kg}^{-1}\right)$, although the organic carbon highest values were observed in the top layers $(5.5 \%)$. The smallest organic carbon values $(1.3 \%)$ were observed at the $20-25 \mathrm{~cm}$ depth, and the smallest $\mathrm{Hg}$ values were observed in deeper layers $(25-30 \mathrm{~cm})$.

\section{DISCUSSION}

The high $\mathrm{Hg}$ concentrations observed in the surface sediment in almost all the studied ecosystems, was probably reflecting recent $\mathrm{Hg}$ input, which was probably transported from adjacent areas by surface runoff or by atmospheric deposition. The atmospheric deposition seems to play an important role in the $\mathrm{Hg}$ cycling in the studied area mainly due to the uncontrolled use of organo mercurial fungicides until 1980 in sugar cane plantations, amplified by the ancient harvesting procedures, like burn the plantations before harvest (Câmara, 1990). In fact, $\mathrm{Hg}$ concentrations in the bulk atmospheric deposition over the Rio de Janeiro Coast has already being measured by some authors. The average $\mathrm{Hg}$ concentration in the bulk atmospheric of Campos was twice $\left(0.51 \mathrm{ngL}^{-1}\right)$ as those measured at a pristine site $\left(0.24 \mathrm{ngL}^{-1}\right)$, although mercury fungicides utilization was banned since the beginning of the eighties. A seasonal trend in $\mathrm{Hg}$ distribution was also observed been associated with the pre-harvest burning of the sugarcane plantations. These studies suggested that for the Campos dos Goytacazes region surface ecosystems were already submitted to anomalous high deposition rates of $\mathrm{Hg}$ (Silva Filho, et al., 1998; Lacerda, et al., 2002). Indeed a study performed in Florida everglades sugarcane area showed that pre-harvest burning in the most significant source of $\mathrm{Hg}$ to that environment (Patrick et al., 1994).

Once in the atmosphere, $\mathrm{Hg}$ diffusing is driven by regional and global atmospheric circulation (Semu,1987). The preferential wind direction in north of Rio de Janeiro state has been northeast, what could explain the lower $\mathrm{Hg}$ concentrations observed in the Iquipari and Açu lagoons (Fig.1) These lagoons are located along the coastline, where the atmospheric influence is preferentially marine. Considering the importance of the surface runoff in the input of material to these lagoons, the lack of sugar cane plantations in these lagoons drainage basin could also explain the lower concentrations found in sediments profiles.

The high average $\mathrm{Hg}$ concentrations observed in Cima lake $\left(158 \mu \mathrm{g} \cdot \mathrm{kg}^{-1}\right)$ was probably due to the presence of sugar cane plantations in its drainage basin and by riverine input. The Imbé River that drains the Imbé Mountains discharges its waters in the Cima Lake. These mountains are considered a natural barrier to northeast wind, apparently retaining a large amount of the material transported by the wind. This trend was confirmed by the high $\mathrm{Hg}$ concentrations observed in soils of the Imbé National Park Forests (up to $298 \mu \mathrm{g} \cdot \mathrm{kg}^{-1}$ ) that presented higher $\mathrm{Hg}$ concentrations than the 


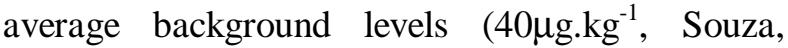
1994) as well as soils where the fungicides was used in the past (78 $\mu \mathrm{g} . \mathrm{kg}^{-1}$, Primo, 2000).

Although both Grussai and Açu Lagoons are located nearby each other (Fig. 1), being submitted to the same climatic and geologic conditions, the first lagoon presented a large area of it's drainage occupied by urban areas. These areas contributed large amount of domestic effluents directly in the lagoon (Suzuki et al., 1998). This anthropogenic influence was probably responsible for the higher $\mathrm{Hg}$ concentration observed in surface sediments of this lagoon when compared to the other coastal systems.

The large variation observed in the profile of Campelo Lake was probably indicating a recent $\mathrm{Hg}$ input to the system. Lacerda and Salomons (1991) observed the same $\mathrm{Hg}$ distribution in lakes from Pantanal, suggesting that the organic matter distribution, characteristic of pristine environments allowed the atmospheric $\mathrm{Hg}$ to accumulate in surface sediment.

Silva (1999) studying $\mathrm{Hg}$ distribution in sediment profiles from Cima Lake, established the sedimentation rate for the lake, and also obtained a good correlation between $\mathrm{Hg}$ concentration peaks and events that occurred in drainage basin. The highest $\mathrm{Hg}$ concentrations, situated around $25 \mathrm{~cm}$ depth, corresponded to the end of the seventies, a period when the organo-mercurial fungicide prohibition was established and gold mining in Paraíba do Sul River was at its climax. The variation of the $\mathrm{Hg}$ peak depth between lakes was probably due to differences in sedimentation rates. The profiles from Feia Lake presented the same results, with increasing $\mathrm{Hg}$ concentrations towards the surface, strengthening the hypothesis of recent Hg enrichment (Fig. 3).

The average $\mathrm{Hg}$ concentration in all sediment profiles studied $\left(64.4 \mu \mathrm{g} \cdot \mathrm{kg}^{-1}\right)$, was twice the background levels observed for the Pantanal $\left(30 \mu \mathrm{g} \cdot \mathrm{kg}^{-1}\right)$; higher than the local background levels $\left(40 \mu \mathrm{g} \cdot \mathrm{kg}^{-1}\right)$, suggested by Souza (1994) and also above the average concentration for no impacted tropical areas $\left(50 \mu \mathrm{g} \cdot \mathrm{kg}^{-1}\right)$. These results indicated that the sediments were contaminated by this element (Table 4).

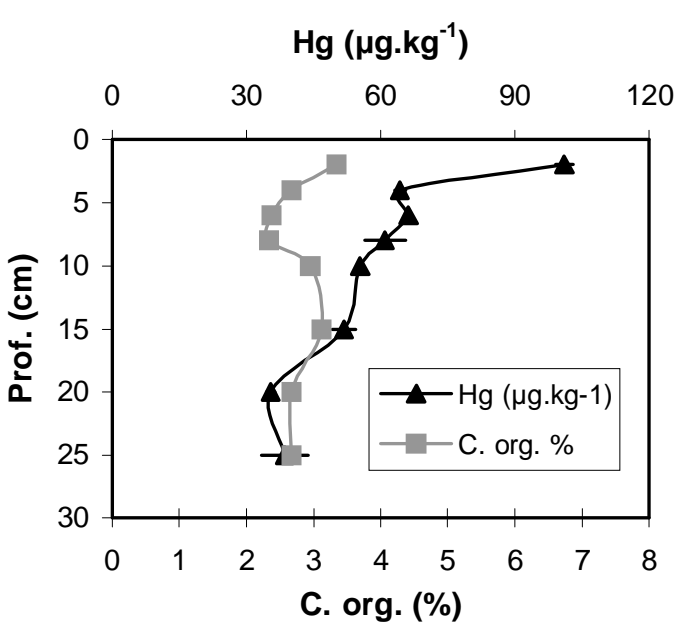

Figure 3 - Mercury and organic carbon distribution in a sediment profile from Feia Lake.

Table 4 - Average or range of mercury $\left(\mu \mathrm{g} . \mathrm{kg}^{-1}\right)$ concentrations in sediment profiles compared with other studies.

\begin{tabular}{|c|c|}
\hline Study area & $\mathrm{Hg}$ \\
\hline $\begin{array}{l}\text { Brazilian lakes background levels } \\
\text { (Pantanal MT). }{ }^{1}\end{array}$ & 30 \\
\hline Contaminated Finland lakes. ${ }^{2}$ & $50-250$ \\
\hline Finland lakes background levels. ${ }^{2}$ & $20-50$ \\
\hline Denmark background levels. ${ }^{3}$ & $151-523$ \\
\hline Contaminated Denmark lakes. ${ }^{3}$ & $243-314$ \\
\hline Background for Tropical areas. ${ }^{4,5}$ & 50 \\
\hline Regional background levels. ${ }^{6}$ & 40 \\
\hline Present study average. & 64 \\
\hline
\end{tabular}

1) Lacerda and Salomons (1991); 2) Recolainen et al. (1986); 3) Madesen (1986); 4) Lacerda et al. (1993); 5) Cavalcante (1990); 6) Souza (1994).

The high variation in $\mathrm{Hg}$ concentration observed in surface sediment and the clear trend of increasing $\mathrm{Hg}$ values towards the surface layers probably indicated recent $\mathrm{Hg}$ inputs. $\mathrm{Hg}$ used in the past was probably distributed and transported according to the regional atmospheric circulation and deposited in lake sediments (Table 5). 
Table 5 - Average or range of mercury $\left(\mu \mathrm{g} \cdot \mathrm{kg}^{-1}\right)$ concentrations in surface sediments compared with other studies.

\begin{tabular}{l|c}
\hline \multicolumn{1}{c|}{ Study area } & Hg \\
& \\
\hline Brazilian Lakes. $^{1}$ & 12 a 80 \\
Canada Background levels. $^{1}$ & 560 \\
Finland Lakes. $^{2}$ & 550 \\
Paraíba do Sul River. $^{3}$ & $300-900$ \\
Muriaé River. $^{4}$ & $90-650$ \\
Maximum permitted levels. $^{5}$ & 100 \\
Present study average. & 95
\end{tabular}

1) Lacerda and Salomons (1991); 2) Recolainen et al. (1986); 3) Pfeiffer et al. (1989); 4) Malm, (1991); 5) SEMA, (1980).

\section{CONCLUSIONS}

Surface sediments from almost all the studied lakes presented values 3 to 4 times higher than the average for non-impacted tropical areas $\left(50 \mu \mathrm{g} \cdot \mathrm{kg}^{-}\right.$ ${ }^{1}$ ), probably indicating recent contamination. Although coastal lagoons such as Iquipari and Açu, presented low $\mathrm{Hg}$ levels near the suggested regional background levels. The higher $\mathrm{Hg}$ values observed in surface sediments of lagoons as Campelo $\left(349.6 \mu \mathrm{g} . \mathrm{kg}^{-1}\right)$ seemed to reinforce the recent $\mathrm{Hg}$ input hypothesis to these systems. Our results also suggested that the $\mathrm{Hg}$ used in the past as fungicide in the sugar cane plantations and in gold mining activities were still transported to adjacent ecosystems.

Organic carbon concentrations in sediments presented in most of the cases a positive correlation with the $\mathrm{Hg}$, showing, at least for the studied areas, that the organic carbon seemed to play an important role in the $\mathrm{Hg}$ retention in sediments.

This study also showed the importance of anthropogenic input of $\mathrm{Hg}$ (as fungicides and gold mining) and the atmospheric transport and dispersion, specially in north of Rio de Janeiro State, where the high values were observed specially in the Cima lake, located near the Imbé mountains an important obstacle to the regional atmospheric transport.

\section{ACKNOWLEDGEMENTS}

The authors would like to thank the technicians Denise Nogueira de Souza and Cristina Siqueira Barreto for helping in the laboratory procedures. Financial support was provided by FENORTE.

\section{RESUMO}

Devido a sua toxicidade e capacidade de se acumular em organismos, o mercúrio é considerado um poluente extremamente perigoso. Suas propriedades associadas às condições ambientais podem resultar em uma larga dispersão. Nas ultimas décadas diversos trabalhos tem demonstrado a contaminação da região Norte do Estado do Rio de Janeiro por Hg, inclusive com casos de contaminação humana. Desta forma, o objetivo do presente estudo é avaliar a distribuição de $\mathrm{Hg}$ em sedimentos de seis lagoas da região norte do Estado do Rio de Janeiro, relacionando as concentrações de $\mathrm{Hg}$ com fatores que podem influenciar sua mobilidade nos sedimentos como o carbono orgânico. As amostras de sedimento superficial foram coletadas ao longo de seis das principais lagoas da região e os perfis foram retirados de pontos centrais das mesmas. Os elevados valores de $\mathrm{Hg}$ observados nos sedimentos superficiais de lagoas como a do Campelo (349,6 $\left.\mu \mathrm{g} . \mathrm{kg}^{-1}\right)$, parecem reforçar a hipótese de entradas recentes deste elemento para o sistema. Os resultados sugerem ainda que o $\mathrm{Hg}$ que foi utilizado no passado proveniente principalmente da aplicação de fungicidas organo-mercuriais e do garimpo de ouro na região, ainda pode estar sendo transportado para sistemas adjacentes. As correlações $\mathrm{Hg} /$ carbono orgânico se mostraram significativamente positivas com $\mathrm{p}<0,05$, indicando que para a região, a matéria orgânica parece possuir papel significativo na retenção do $\mathrm{Hg}$.

\section{REFERENCES}

Bastos, W. R.; Malm, O.; Pfeiffer, W. C. and Cleary, D. (1998), Establishment and Analytical Quality Control of Laboratories for $\mathrm{Hg}$ Determination in Biological and Geological Samples in the Amazon, Brazil. Ciência e Cultura., 50 : (4), 255-260.

Calasans, C. V. C. (1998), Origem e dinâmica da matéria orgânica em um sistema fluvio-lacustre da Região Norte Fluminense. Ph.D. Thesis, Universidade Estadual do Norte Fluminense. Campos dos Goytacazes, RJ. 100 pp.

Câmara, V. M. (1990), O caso de Campos - RJ Estudos do quadro de morbilidade causado pela exposição pregressa dos trabalhadores aos fungicidas organomercuriais. In: Riscos e Conseqüências do Uso do Mercúrio. SeminárioNacional. Rio de Janeiro : FINEP/CNPq/MS/ IBAMA. pp. 229-246. 
Cavalcante, P. R. S.; Costa M. L. and Tarouco J. E. F., (1990), Avaliação preliminar dos níveis de mercúrio da porção interna do golfão maranhense. In: Riscos $e$ conseqüência do uso do mercúrio. Rio de Janeiro : FINEP/CNPq/MS/IBAMA. pp. 46-49.

Kudo, A. (1977), Equilibrium concentrations of methylmercury in Ottawa River sediment. Nature; 270, 419-420.

Lacerda L. D. and Solomons, W. (1991), Mercury in the Amazon: A chemical time bomb? Dutch Ministry of Housing, Physical Planning and Environment. 46 pp.

Lacerda L. D.; Carvalho, C. E. V.; Rezende, C. E. and Pfeiffer, W. C. (1993), Mercury in sediments of the Paraíba do Sul River Continental Shelf, S. E. Brazil. Marine Pollution Bulletin, 26 : (4), 220-222.

Lacerda, L. D.; Paraquetti, H. H. M.; Rezende, C. E.; Silva, L. F. F.; Silva Filho, E. V. Marins, R. V. and Ribeiro, M. G. (2002), Mercury concentrations in bulk atmospheric deposition over the coast of Rio de Janeiro, Southeast, Brazil. J.Braz. Chem. Soc., 13 : (2), 165-169.

Lima, E. C. R. (1990), Riscos e conseqüências do uso do mercúrio: A situação do Rio de Janeiro In: Riscos e Conseqüências do uso do mercúrio. Rio de Janeiro : FINEP/CNPq/MS/IBAMA. pp. 268-274.

Lodenius, M. and Malm O. (1998), Mercury in Amazon. Rev. Environm. Contam. Toxicol., 157, 2552.

Malm O.; Pfeiffer W. C. and Souza C. M. M. (1991), Main pathways of mercury in Madeira river area, Rondonia, Brazil. In: Paper presented at the $8^{\text {th }}$ Intern. Conf. on Heavy Metals in the Environment, Edinburgh, Scotland.

Patrick, W. H.; Gambrel, R. P.; Parkplan, P. and Tau, F. (1994), Mercury in soils and plants in the Florida Everglades sugarcane area. In: Watras, C. J. and Huckabee, J. W. (Eds.). Mercury Pollution: Integration and Synthesis.. Boca Raton : Lewis Publ. pp. 609.

Primo, W. S. (2000), Distribuição de mercúrio e carbono orgânico em solos e sedimentos da região Norte do Estado do Rio de Janeiro. Master Thesis, Universidade Estadual do Norte Fluminense, Campos dos Goytacazes, Brazil.

Pfeiffer, W. C.; Souza, C. M. M.; Bastos, W. R.; Torres, J. P. M. and Malm, O. (1989), Mercury pollution in the gold mining areas of the state of Rio de Janeiro, Brazil. In: Paper presented at the $7^{\text {th }}$. Inter. Conf. Heavy Metals in the Environment, Geneve, Switzerland.

Recolainen, S.; Verta, M. and Liehu, A. (1986), The effect of airborne mercury contents in some Finnish forest lake. Publ. Water Res. Inst. Finland, 65, 11-20.

Semu, E. and Singh B. R. (1987), Absorption of mercury compounds by tropical soils. Water Air and Soil Pollution, 32, 1-10.
SEMA. (1980), Avaliação dos projetos de metais pesados. Coordenadoria de Controle de Poluição do Solo. SEMA, MINTER. Brasília, Vol. Ilustrado.

Silva, M. A. L. (1999), Acumulação de sedimentos e distribuição de matéria orgânica e metais pesados em sedimentos da Lagoa de Cima, Campos. RJ. Master Thesis, Universidade Estadual do Norte Fluminense, Campos dos Goytacazes, Brazil.

Silva-Filho, E. V.; Paiva, R. P.; Wasserman, J. C. and Lacerda, L. D. (1998), Geochemical characterization of rain water particulate material on a coastal subtropical region in Brazil. J. Braz. Chem. Soc., 9 : (5), 482-486.

Souza, C. M. M. (1994), Avaliação ambiental dos riscos do mercúrio em áreas de garimpo de Brasil. $\mathrm{PhD}$. Thesis, Universidade Federal do Rio de Janeiro, Rio de Janeiro, Brasil.

Suzuki,M. S.; Ovalle, A. R. C. and Pereira, E. A. (1998), Effects of sand bar openings on some limnological variables in a hipertrophic coastal lagoon, Brazil. Hydrobiologia, 368, 111-122.

Received: April 15, 2002; Revised: December 26, 2002; Accepted: July 23, 2003. 